\title{
Pengaruh kompetensi, pelatihan dan pengawasan terhadap kinerja karyawan pada PT Rubber Hock Lie Sunggal Sumatra Utara
}

\author{
Hernadhi. S \\ Jurusan Manajemen, Fakultas Ekonomi,Universitas Prima Indonesia \\ E-mail korespodensi: hernadhitonga1997@gmail.com
}

\begin{abstract}
Performance is the level of success of employees in carrying out their duties. Factors that affect employee performance are competence, training, and supervision. Competence is the ability to carry out a job that is based on skills and knowledge. Training is a process of improving employee job skills to help achieve company goals. Supervision is a process to ensure that all activities are carried out according to what has been planned. PT. Rubber Hock Lie is an international industrial company headquartered in Singapore which produces crumb rubber. The research method uses a quantitative approach, the type of research used is descriptive quantitative. The data analysis used is multiple linear regression. To test the validity and reliability of the research variable instruments, 30 respondents were taken out of the sample. The results showed that competence, training, and supervision simultaneously and partially had a positive and significant effect on employee performance with a coefficient of determination of 0.937 or $93.7 \%$, while the remaining $6.3 \%$ was influenced by other factors. The conclusion of this research is that competency, training, and supervision simultaneously and partially have a significant effect on the performance of the employees of PT Rubber Hock Lie Sunggal.
\end{abstract}

Keywords: Competence, Training, Supervision, Performance

\begin{abstract}
Abstrak
Kinerja merupakan tingkat keberhasilan karyawan dalam melaksanakan tugasnya. Faktor yang mempengaruhi kinerja karyawan adalah kompetensi, pelatihan dan pengawasan. Kompetensi adalah suatu kemampuan untuk melaksanakan suatu pekerjaan yang dilandasi atas keterampilan dan pengetahuan. Pelatihan merupakan proses memperbaiki keterampilan kerja karyawan untuk membantu pencapaian tujuan perusahaan. Pengawasan adalah proses untuk memastikan bahwa segala aktifitas yang terlakasana sesuai dengan apa yang telah di rencanakan. PT. Rubber Hock Lie merupakan perusahaan yang bergerak dibidang industri berskala internasional berpusat di Singapura yang memproduksi karet remah. Metode penelitian menggunakan pendekatan kuantitatif, jenis penelitian yang digunakan deskriptif kuantitatif. Analisis data yang digunakan adalah regresi linier berganda. Untuk uji validitas dan reliabilitas intrumen variabel penelitian diambil 30 orang responden di luar sampel. Hasil penelitian menunjukkan bahwa kompetensi, pelatihan dan pengawasan secara simultan dan parsial berpengaruh positif dan signifikan terhadap kinerja karyawan dengan nilai koefisien determinansi sebesar 0,937 atau $93,7 \%$, sedangkan sisanya $6,3 \%$ dipengaruhi oleh faktor-faktor lain. Kesimpulan penelitian adalah secara serempak dan parsial kompetensi, pelatihan dan pengawasan berpengaruh signifikan terhadap kinerja karyawan PT Rubber Hock Lie Sunggal.
\end{abstract}

Kata kunci: Kompetensi, Pelatihan, Pengawasan, Kinerja 


\section{PENDAHULUAN}

Perusahaan yang bergerak dalam bidang industri baik perusahaan kecil menengah maupun besar di Indonesia, selalu dihadapkan pada persaingan yang semakin kompetitif. Dalam menghadapi persaingan tersebut tentunya tidak cukup hanya dengan menggunakan teknologi canggih dalam produksi dan kegiatan operasional perusahaan.

Salah satu faktor yang dapat dijadikan pegangan perusahaan dalam menciptakan keunggulan bersaing adalah dengan keunggulan Sumber Daya Manusia yang berkualitas yang akan memberikan kontribusi bagi keunggulan bersaing era globalisasi. Sumber Daya Manusia yang dimaksud adalah karyawan perusahaan.

Kinerja karyawan merupakan salah satu faktor yang sangat mempengaruhi keberhasilan perusahaan. Dimana, kinerja merupakan hasil kerja serta kualitas dan kuantitas yang dicapai oleh seseorang pegawai dalam melaksanakan tugasnya sesuai dengan tanggung jawab yang diberikan kepadanya.

Untuk itu kenapa kinerja sangat penting di dalam perusahaan, karena kinerja karyawan yang menentukan tingkat keberhasilan perusahaan itu sendiri dari jumlah target yang dihasilkan dan juga dari hasil produksi yang dihasilkan mempunyai kualitas yang baik, sehingga pencapaian yang diperoleh SDM akan memberikan kontribusi bagi perusahaan. Kinerja karyawan dapat di pengaruhi beberapa faktor seperti kompetensi, pelatihan, pengawasan dan lain sebagainya.

Kompetensi merupakan karakteristik yang mendasari diri seseorang atau karyawan berkaitan dengan efektivitas yang memberikan kinerja dalam pekerjaan, peran, atau situasi tertentu dalam sebuah organisasi. Dengan demikian, kompetensi merupakan kombinasi dari keterampilan, pengetahuan dan perilaku, yang dapat diamati dan diterapkan secara kritis untuk suksesnya sebuah organisasi dan menjadi sangat penting dan berguna bagi karyawan dalam meningkatkan kinerjanya.

Disamping itu, pelatihan juga memiliki peran penting yang merupakan suatu upaya perusahaan dalam mengasah dan meningkatkan kemampuan serta keterampilan karyawan dalam bidang akademis maupun teknis yang kemudian juga digunakan sebagai wadah pengembangan dan perbaikan kinerja yang buruk yang dilakukan karyawan. Hal ini yang wajib dilakukan perusahaan untuk mempertahankan kinerja karyawan agar tetap stabil dan kemudian dapat meningkat dari waktu ke waktu.

Selain kompetensi dan pelatihan, pengawasan kerja juga merupakan suatu hal yang wajib dilakukan dalam perusahaan untuk meningkatkan kinerja Sumber Daya Manusianya. Pengawasan kerja adalah serangkaian proses mengorganisir yang bertujuan untuk mengarahkan para karyawan agar melakukan pekerjaannya dengan baik dan tepat agar berjalan sesuai dengan yang diharapkan oleh atasan guna tercapainya target perusahaan, serta membentuk suatu kondisi yang tercipta melalui proses dari serangkaian perilaku yang menunjukan nilai-nilai ketaatan, kepatuhan, kesetiaan, keteraturan dan ketertiban.

PT. Rubber Hock Lie Sunggal Sumatera Utara adalah sebuah perusahaan yang bergerak dibidang industri berskala internasional berpusat di Singapura yang memproduksi karet remah (crumb rubber), yaitu karet alam yang diproses selanjutnya menjadi barang setengah jadi, seperti ban dan produk karet lainnya. Produk crumb rubber dari perusahaan ini umumnya di ekspor ke Asia Tenggara, Cina, Afrika Selatan, Eropa, Inggris Raya dan Amerika Serikat untuk industri produk bahan jadi karet seperti pabrik ban dan produk-produk lainnya yang berbahan karet.

Berdasarkan latar belakang yang telah diuraikan sebelumnya, maka peneliti mengidentifikasi masalahnya adalah: 1).Kompetensi yang masih kurang baik, dilihat dari tingkat pendidikan yang tidak seimbang dalam setiap divisi di PT. Rubber Hock Lie Deli 
Serdang. 2).Pelatihan kurang efektif dilihat dari data pelatihan yang telah dilakukan perusahaan dimana masih ada karyawan yang tidak mengikuti pelatihan karena program pelatihan yang kurang sesuai dengan kebutuhan karyawan serta kurang berhubungan dengan praktek dilapangan. 3).Pengawasan mengalami masalah, dapat dilihat dari kesalahan kerja oleh pengawas yang dilakukan dalam bekerja di PT.Rubber Hock Lie Deli Serdang Sumatera Utara. 4).Kinerja karyawan mengalami masalah, terlihat dari tabel produksi perusahaan dimana banyaknya produksi yang tidak mencapai target perbulan PT. Rubber Hock Lie Deli Serdang Sumatera Utara.

\section{LANDASAN TEORI}

Menurut Fahmi (2016:45), Kompetensi adalah kemampuan yang dimiliki oleh seorang individu yang memiliki nilai jual dan itu teraplikasi dari hasil kreativitas serta inovasi yang dihasilkan.

Menurut Sutrisno $(2009 ; 205)$, SDM dapat bertahan karena mereka memiliki kompetensi manajeral, yaitu kemampuan merumuskan visi dan strategi perusahaan serta kemampuan untuk memperoleh dan mengarahkan sumber daya lain dalam rangka mewujudkan visi dan menerapkan strategi perusahaan.

Menurut Wibowo (2014:272-273), indicator kompetensi dapat diukur melalui 5 karateristik,yaitu sebagai berikut: 1).Motif. 2).Sifat. 3).Konsep diri. 4).Pengetahuan. 5).Keterampilan. Menurut Bangun (2012:202), "Pelatihan adalah suatu proses memperbaiki keterampilan kerja karyawan untuk membantu pencapaian tujuan perusahaan". Menurut Handoko (2014:104), "Menyebutkan pelatihan (training) dimaksudkan untuk memperbaiki penguasaan berbagai keterampilan dan teknik pelaksanaan kerja tertentu, terinci dan rutin".

Menurut Mangkunegara (2011:44), indikator pelatihan adalah: 1).Tujuan ,2).Para Pelatih (trainers), 3).Materi latihan, 4).Metode pelatihan, 5).Peserta pelatihan. Menurut Saefullah (2013:317-318) pengawasan adalah proses untuk memastikan bahwa segala aktifitas yang terlakasana sesuai dengan apa yang telah di rencanakan. Menurut Daulay dkk (2016:182), suatu pengawasan di katakan penting karena tanpa adanya pengawasan yang baik tentunya akan menghasilkan tujuan yang kurang memuaskan, baik bagi organisasinya itu sendiri maupun bagi para pekerjanya.

Menurut Siswandi (2011:207), untuk menjadi efektif, sistem pengawasan harus memenuhi kriteria tertentu. Kriteri-kriteria utama adalah sistem seharusnya: 1).Akurat , 2).Tepat waktu, 3).Objektif dan menyeluruh, 4).Terpusat pada titik pengawasan strategic. 5).Realistic secara ekonomi, 6).Realistic secara organisasional, 7).Terkordinasi dengan aliran kerja organisasi, 8).Fleksibel, 9).Bersifat sebagai petunjuk dan oprasional, 10).Di terima pada anggota organisasi

Menurut Fahmi (2016:137) kinerja adalah hasil yang diperoleh oleh suatu organisasi baik organisasi tersebut profit oriented dan non profit oriented yang dihasilkan selama satu periode.

Menurut Mangkunegara (2013:67) bahwa kinerja adalah hasil kerja secara kualitas dan kuantitas yang dicapai oleh seseorang karyawan dalam melaksanakan tugasnya sesuai dengan tangung jawab yang diberikan padanya.

Menurut Wibowo (2016:86) terdapat tujuh indikator kinerja karyawan yaitu: 1).Tujuan, 2).Standar, 3).Umpan balik, 4).Alat atau sarana, 5).Kompetisi, 6).Motif. Berdasarkan tinjauan pustaka yang diuraikan sebelumnya mengenai variabel kompetensi, pelatihan dan pengawasan serta pengaruhnya terhadap kinerja karyawan, maka dapat disimpulkan sebagai berikut: 


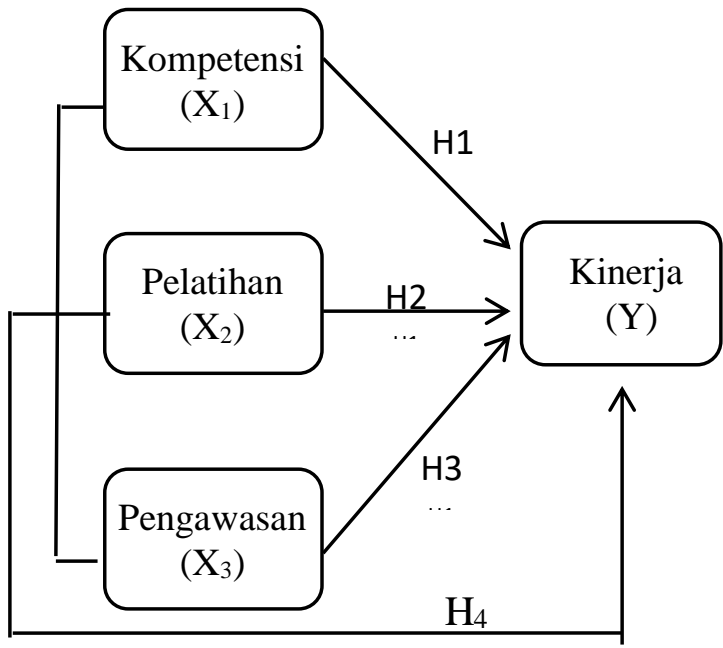

Berdasarkan kerangka konseptual tersebut, dapat ditarik sebuah hipotesis penelitian yaitu:

$\mathrm{H}_{1}$ : Kompetensi berpengaruh terhadap kinerja karyawan pada PT Rubber Hock Lie.

$\mathrm{H}_{2}$ : Pelatihan berpengaruh terhadap kinerja karyawan pada PT Rubber Hock Lie.

$\mathrm{H}_{3}$ : Pengawasan berpengaruh terhadap kinerja karyawan pada PT Rubber Hock Lie.

$\mathrm{H}_{4}$; Kompetensi, Pelatihan dan Pengawasan berpengaruh terhadap kinerja karyawan pada PT Rubber Hock Lie.

\section{METODE}

Penelitian ini dilakukan pada perusahaan PT Rubber Hock Lie Sunggal Sumatera Utara, yang beralamat di Jl Stasiun No 11, Desa Tanjung Gusta, Kecamatan Medan Sunggal. Waktu penelitian dilakukan dari bulan Juli 2019 dan diperkirakan akan selesai pada bulan Juli 2020.

Metode penelitian menggunakan pendekatan kuantitatif, jenis penelitian yang digunakan deskriptif kuantitatif. Pengumpulan data dilakukan dengan wawancara, kuisioner dan studi dokumentasi. Analisis data yang digunakan adalah regresi linier berganda. Populasi adalah seluruh karyawan yang berjumlah 150 orang. Sampel dalam penelitian ini berjumlah 109 orang yang di tentukan menggunakan rumus Slovin. Untuk uji validitas dan reliabilitas intrumen variabel penelitian diambil 30 orang responden di luar sampel.

\section{Uji validitas}

Uji validitas menurut Ghozali (2009:49) pada dasarnya instrumen penelitian, menunjukkan pada seperangkat alat yang digunakan untuk mengukur suatu fenomena sesuai dengan variabel yang diteliti.

Tabel 1. Rangkuman hasil uji validitas

\begin{tabular}{ccccl}
\hline No & Variabel & $\begin{array}{c}\text { Jumlah } \\
\text { Item }\end{array}$ & $\begin{array}{c}\text { Jumlah } \\
\text { Valid }\end{array}$ & Keterangan \\
\hline 1 & Kompetensi $\left(\mathrm{X}_{1}\right)$ & 10 & 10 & Semua Valid \\
2 & Pelatihan $\left(\mathrm{X}_{2}\right)$ & 10 & 10 & Semua Valid \\
3 & Pengawasan $\left(\mathrm{X}_{3}\right)$ & 10 & 10 & Semua Valid \\
4 & Kinerja $(\mathrm{Y})$ & 10 & 10 & Semua Valid \\
\hline
\end{tabular}

Sumber: Data diolah, 2020 
Instrumen yang valid berarti alat ukur yang digunakan untuk mendapatkan data yang valid. Jika valid berarti instrumen dapat digunakan mengukur yang hendak diukurnya (ketetapan alat ukur).

\section{Uji reliabilitas}

Menurut Ghozali (2009:130), kuesioner dikatakan reliabel atau handal jika jawaban seseorang terhadap pertanyaan konsistem atau stabil dari waktu ke waktu.Pengujian dilakukan dengan mencoba instrumen sekali saja, kemudian data yang diperoleh dianalisis dengan teknik tertentu, dalam hal ini teknik yang digunakan adalah cronbach Alpha (a). Suatu variabel dikatakan reliabel jika memberikan nilai $a>0,70$.

Tabel 2. Hasil pengujian reliabilitas instrument penelitian

\begin{tabular}{clccc}
\hline No & Variabel Penelitian & $\begin{array}{c}\text { Cronbach's } \\
\text { Alpha }\end{array}$ & N of Items & Keterangan \\
\hline 1 & Kompetensi $\left(\mathrm{X}_{1}\right)$ & 0,914 & 10 & Reliabel \\
2 & Pelatihan $\left(\mathrm{X}_{2}\right)$ & 0,906 & 10 & Reliabel \\
3 & Pengawasan $\left(\mathrm{X}_{3}\right)$ & 0,898 & 10 & Reliabel \\
4 & Kinerja $(\mathrm{Y})$ & 0,911 & 10 & Reliabel \\
\hline
\end{tabular}

Sumber: Data diolah, 2020

\section{HASIL DAN PEMBAHASAN}

\section{Hasil uji asumsi klasik}

Sebelum menguji hipotesis, dilakukan pengujian asumsi klasik untuk memastikan bahwa alat uji regresi linier berganda dapat digunakan atau tidak. Apabila uji asumsi klasik telah terpenuhi, maka alat uji statistik regresi berganda dapat digunakan. Uji asumsi klasik dalam hal ini berupa uji normalitas, uji multikolinieritas dan uji heteroskedastisitas.

\section{Uji normalitas}

Uji normalitas bertujuan menguji apakah dalam model regresi, variabel pengganggu atau residual berdistribusi normal. Ada dua cara untuk mendeteksi apakah residual berdistribusi normal atau tidak, yaitu dengan analisis grafik dan uji statistik. Untuk melihat residual penulis menganalisis probabilitas plot yang membandingkan distribusi kumulatif dan distribusi normal.

Tabel 3. Tabel one sampel Kolmogorov-Smirnov

\begin{tabular}{llr}
\hline & & Unstandardized residual \\
\hline $\mathrm{N}$ & & $\mathbf{1 0 9}$ \\
Normal Parameters & &, 0000000 \\
& Sean & 1,33311572 \\
& Std. Deviation &, 070 \\
Most Extreme Differences & Absolute &, 070 \\
& Positive &,- 068 \\
& Negative &, 070 \\
Test Statistic & &, $200^{\mathrm{c}, \mathrm{d}}$ \\
Asymp. Sig. (2-tailed) & &
\end{tabular}

Sumber: Data diolah, 2020 
Berdasarkan Tabel 3 tersebut, dapat diketahui nilai signifikan (Asymp.Sig) sebesar 0,200 , lebih besar dari signifikan $5 \%(0,05)$, maka data tersebut dinyatakan dinyatakan residual berdistribusi normal.

\section{Uji multikolinieritas}

Uji multikolinieritas bertujuan untuk menguji apakah dalam model regresi ditemukan korelasi antar variabel independen dan hal ini dapat dilihat dari VIF dengan catatan apabila VIF > 10 maka diduga mempunyai persoalan multikolinier dan apabila VIF $<10$ dan nilai tolerance $>0,1$ maka tidak terjadi multikolinieritas.

Model regresi yang baik seharusnya tidak terjadi korelasi antara variabel indepen. Hasil pengujian dapat dilihat pada Tabel 4 berikut ini:

Tabel 4. Hasil uji multikolinieritas

\begin{tabular}{|c|c|c|c|c|c|c|c|c|}
\hline & \multirow{2}{*}{ Model } & \multicolumn{2}{|c|}{$\begin{array}{c}\text { Unstandardized } \\
\text { Coefficients }\end{array}$} & \multirow{2}{*}{$\begin{array}{c}\begin{array}{c}\text { Standardized } \\
\text { Coefficients }\end{array} \\
\text { Beta }\end{array}$} & \multirow[t]{2}{*}{$\mathbf{t}$} & \multirow[t]{2}{*}{ Sig. } & \multicolumn{2}{|c|}{ Collinearity Statistics } \\
\hline & & B & $\begin{array}{l}\text { Std. } \\
\text { Error }\end{array}$ & & & & Tolerance & VIF \\
\hline \multirow[t]{4}{*}{1} & (Constant) & 2,404 & ,631 & & 3,812 & ,000 & & \\
\hline & Kompetensi & ,465 &, 034 &, 546 & 13,784 & ,000 & ,371 & 2,693 \\
\hline & Pelatihan & , 116 &, 056 &, 132 & 2,086 & 039 &, 145 & 6,881 \\
\hline & Pengawasan & ,329 &, 059 &, 354 & 5,609 &, 000 &, 147 & 6,819 \\
\hline
\end{tabular}

a. Dependent Variable: Kinerja

Sumber: Data diolah, 2020

Berdasarkan Tabel 4 tersebut diatas, dapat dijelaskan bahwa nilai tolerance masingmasing variabel independen $\mathrm{X}_{1}$ sebesar $0,371, \mathrm{X}_{2}$ sebesar 0,145 dan $\mathrm{X}_{3}$ sebesar 0,147 lebih besar dari 0,1 sedangkan nilai VIF tiap variabel independen X1 sebesar 2,693,X2 sebesar 6,881 dan X3 sebesar 6,819 lebih kecil dari 10, maka data tersebut dinyatakan tidak terjadi gejala multikolinieritas.

\section{Uji heteroskedastisitas}

Uji heteroskedastisitas bertujuan untuk mengetahui apakah dalam sebuah model regresi terjadi kesamaan varians residual. Sebuah model regresi yang baik adalah tidak terjadi heteroskedastisitas. Berikut adalah hasil pengujian metode Glejser:

Tabel 5. Hasil uji heteroskedastisitas metode glejser

\section{Coefficients $^{\mathrm{a}}$}

\begin{tabular}{llllll}
\hline \multirow{2}{*}{ Model } & \multicolumn{2}{c}{$\begin{array}{c}\text { Unstandardized } \\
\text { Coefficients }\end{array}$} & $\begin{array}{c}\text { Standardized } \\
\text { Coefficients }\end{array}$ & t & \multirow{2}{*}{ Sig. } \\
\cline { 2 - 5 } & $\mathbf{B}$ & Std. Error & Beta & & \\
\hline $1 \quad$ (Constant) & 1,016 &, 398 & & 2,555 &, 012 \\
$\quad$ Kompetensi &,- 022 &, 021 &,- 166 & $-1,046$ &, 298 \\
Pelatihan &,- 003 &, 035 &,- 021 &,- 083 &, 934 \\
Pengawasan &, 025 &, 037 &, 174 &, 686 &, 494 \\
\hline
\end{tabular}

a. Dependent Variable: RES_2

Sumber: Data diolah, 2020

Berdasarkan Tabel 5 dapat dilihat bahwa nilai sig. tiap variabel independen $\mathrm{X}_{1}$ sebesar 0,298, $X_{2}$ sebesar 0,934 dan $X_{3}$ sebesar 0,494 lebih besar dari nilai signifikansinya 0,05 maka data tersebut dinyatakan terbebas dari masalah heteroskedastisitas. 


\section{Statistik deskriptif}

Berdasarkan analisis statistik deskriptif ditampilkan karakteristik sampel dalam penelitian ini meliputi; jumlah sampel $(\mathrm{N})$, rata-rata sampel (mean), nilai maksimum, nilai minimum serta nilai standar deviasi untuk masing-masing variable.

Tabel 6. Analisis statistik deskriptif

\begin{tabular}{llllll}
\hline & N & Minimum & Maximum & Mean & Std. Deviation \\
\hline Kompetensi & 109 & 16 & 39 & 26,61 & 6,328 \\
Pelatihan & 109 & 15 & 39 & 27,27 & 6,114 \\
Pengawasan & 109 & 17 & 39 & 26,89 & 5,798 \\
Kinerja & 109 & 17 & 37 & 26,79 & 5,387 \\
Valid N (listwise) & 109 & & & &
\end{tabular}

Sumber: Data diolah, 2020

Berdasarkan Tabel 6 tersebut, analisis statistik deskriptif masing-masing variabel penelitian yang terdiri dari; Kompetensi $\left(\mathrm{X}_{1}\right)$ dengan sampel 109 orang responden memiliki jumlah penilaian rata-rata sebesar 26,61, standar deviasi sebesar 6,328, nilai maksimum sebesar 39 yang terdapat pada responden nomor 2 dan nilai minimum sebesar 16 yang terdapat pada responden nomor 8 .

Variabel pelatihan $\left(\mathrm{X}_{2}\right)$ dengan sampel sebanyak 109 responden memiliki jumlah penilaian rata-rata sebesar 27,27 dengan standar deviasi sebesar 6,114, nilai maksimum sebesar 39 yang terdapat pada responden nomor 23 dan nilai minimum sebesar 15 yang terdapat pada responden nomor 88 .

Variabel pengawasan $\left(\mathrm{X}_{3}\right)$ dengan sampel sebanyak 109 responden memiliki jumlahpenilaian rata-rata sebesar 26,89 dengan standar deviasi sebesar 5,798, nilai maksimum sebesar 39 yang terdapat pada responden nomor 2 dan nilai minimum sebesar 17 yang terdapat pada responden nomor 68 .

Variabel kinerja (Y) dengan sampel sebanyak 109 responden memiliki jumlah penilaian rata-rata sebesar 26,79 dengan standar deviasi sebesar 5,387, nilai maksimum sebesar 37 yang terdapat pada responden nomor 70 dan nilai minimum sebesar 17 yang terdapat pada responden nomor 68.

\section{Analisis persamaan regresi linier berganda}

Model analisis ini digunakan untuk mengetahui pengaruh variabel independen terhadap variabel dependen. Hasil koefisien regresi linier berganda variabel-variabel independen $(\mathrm{X})$ terhadap variabel $\mathrm{Y}$ dapat dilihat padatabel berikut ini.

Tabel 7. Hasil uji regresi linier berganda

\section{Coefficients $^{\mathrm{a}}$}

\begin{tabular}{lllclll}
\hline \multirow{2}{*}{ Model } & & \multicolumn{2}{c}{$\begin{array}{c}\text { Unstandardized } \\
\text { Coefficients }\end{array}$} & $\begin{array}{c}\text { Standardized } \\
\text { Coefficients }\end{array}$ & t & Sig. \\
\cline { 3 - 6 } & & B & Std. Error & Beta & & \\
\hline 1 & (Constant) & 2,404 &, 631 & & 3,812 &, 000 \\
& Kompetensi &, 465 &, 034 &, 546 & 13,784 &, 000 \\
& Pelatihan &, 116 &, 056 &, 132 & 2,086 &, 039 \\
& Pengawasan &, 329 &, 059 &, 354 & 5,609 &, 000 \\
\hline
\end{tabular}

a. Dependent Variable: Kinerja

Sumber: Data diolah, 2020

Berdasarkan Tabel 7 dapat diperoleh persamaan regresi linier berganda sebagai berikut:

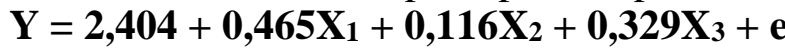


Dari persamaan regresi linier berganda diatas dapat dijelaskan hal-hal sebagai berikut: 1).Nilai konstanta (a) sebesar 2,404 artinya bahwa jika tidak terdapat variabel kompetensi, pelatihan dan pengawasan, maka nilai kinerja sebesar 2,404 satuan. 2).Variabel kompetensi sebesar 0,465 bernilai positif yang artinya bahwa setiap kenaikan variabel kompetensi 1 satuan, maka nilai variabel kinerja akan naik sebesar 0,465 satuan. 3).Variabel pelatihan sebesar 0,116 bernilai positif yang artinya bahwa setiap kenaikan variabel pelatihan 1 satuan, maka nilai variabel kinerja akan naik sebesar 0,116 satuan. 4).Variabel pengawasan sebesar 0,329 bernilai positif yang artinya bahwa setiap kenaikan variabel pengawasan 1 satuan, maka nilai variabel kinerja akan naik sebesar 0,329 satuan.

\section{Koefisien determinansi hipotesis $\left(\mathbf{R}^{2}\right)$}

Koefisien determinansi $\left(\mathrm{R}^{2}\right)$ digunakan untuk mengukur seberapa jauh kemampuan model dalam menerangkan variansi variabel dependen, dimana nilai $\mathrm{R}^{2}$ berkisar antara 0 $<\mathrm{R}^{2}<1$. Semakin besar nilai koefisien determinansi, maka semakin baik kemampuan varian dan variabel bebas menerangkan variabel terikat. Nilai koefisien determinansi ditentukan dengan nilai $\mathrm{R}$ square yang dapat dilihat pada Tabel 9 berikut:

Tabel 8. Nilai koefisien determinansi (R square)

Model Summary

\begin{tabular}{|c|c|c|c|c|}
\hline Model & $\mathbf{R}$ & R Square & $\begin{array}{l}\text { Adjusted R } \\
\text { Square }\end{array}$ & $\begin{array}{l}\text { Std. Error of the } \\
\text { Estimate }\end{array}$ \\
\hline 1 &, $969^{\mathrm{a}}$ & ,939 & ,937 & 1,352 \\
\hline
\end{tabular}

a. Predictors: (Constant), Pengawasan, Kompetensi, Pelatihan

Berdasarkan Tabel 8 diatas, nilai adjusted $\mathrm{R}$ square adalah 0,937 yang artinya bahwa kemampuan variansi varibel kompetensi, pelatihan dan pengawasan dapat menjelaskan variansi kinerja adalah sebesar 93,7\% dan sisanya 6,3\% merupakan variabel lain yang tidak diteliti dalam penelitian ini seperti lingkungan kerja fisik dan non fisik, disiplin kerja, kompensasi, sress kerja, dan lain sebagainya.

\section{Pengujian hipotesis secara simultan (Uji F)}

Uji F atau uji simultan dilakukan untuk mengetahui pengaruh atau hubungan positif dan signifikansi variabel bebas yaitu harga dan kualitas pelayanan terhadap variabel terikat yaitu keputusan pembelian. Model hipotesis yang digunakan dalam uji $\mathrm{F}$ ini dimana: 1$) \cdot \mathrm{H}_{0}: \mathrm{b} 1, \mathrm{~b} 2, \mathrm{~b} 3=0$ (Kompetensi, pelatihan dan pengawasan secara simultan tidak berpengaruh terhadap kinerja karyawan pada PT Rubber Hock Lie Sunggal), 2). $\mathrm{H}_{1}: \mathrm{b} 1, \mathrm{~b} 2, \mathrm{~b} 3 \neq 0$ (Kompetensi, pelatihan dan pengawasan secara simultan berpengaruh terhadap kinerja karyawan pada PT Rubber Hock Lie Sunggal). Hasil pengujian ini dapat dilihat pada Tabel 9 berikut ini:

Tabel 9. Hasil uji F

\begin{tabular}{lllllll}
\hline Model & & $\begin{array}{l}\text { Sum of } \\
\text { Squares }\end{array}$ & df & Mean Square & F & Sig. \\
\hline 1 & Regression & 2942,209 & 3 & 980,736 & 536,515 &, $000^{\mathrm{b}}$ \\
& Residual & 191,937 & 105 & 1,828 & & \\
Total & 3134,147 & 108 & & & \\
\hline
\end{tabular}

a. Dependent Variable: Kinerja

b. Predictors: (Constant), Pengawasan, Kompetensi, Pelatihan

Sumber: Data diolah, 2020

Berdasarkan Tabel 9 dapat dilihat bahwa nilai $F_{\text {hitung }}$ adalah sebesar 980,736 sedangkan $F_{\text {tabel }}$ sebesar 2,69. Dari hasil ini diketahui $F_{\text {hitung }}>F_{\text {tabel }}$ dan signifikansi 0,000 
$<0,05$, maka hasil penelitian menunjukkan bahwa secara simultan $\mathrm{H}_{1}$ diterima dan $\mathrm{H}_{0}$ ditolak. Hal ini menunjukkan bahwa kompetensi, pelatihan dan pengawasan berpengaruh positif dan signifikan terhadap kinerja karyawan pada PT Rubber Hock Lie Sunggal.

\section{Pengujian hipotesis secara parsial (Uji t)}

Uji parsial (uji t) dilakukan untuk menguji secara parsial variabel bebas yang terdiri dari kompetensi, pelatihan dan pengawasan mempunyai pengaruh yang positif dan signifikan terhadap kinerja karyawan pada PT Rubber Hock Lie Sunggal.

Tabel 10. Hasil uji t hipotesis

\section{Coefficients $^{\mathrm{a}}$}

\begin{tabular}{llccccc}
\hline \multirow{2}{*}{ Model } & & \multicolumn{2}{c}{$\begin{array}{c}\text { Unstandardized } \\
\text { Coefficients }\end{array}$} & $\begin{array}{c}\text { Standardized } \\
\text { Coefficients }\end{array}$ & \multirow{2}{*}{ t } & Sig. \\
\cline { 2 - 5 } & & B & Std. Error & Beta & & \\
\hline 1 & (Constant) & 2,404 &, 631 & & 3,812 &, 000 \\
& Kompetensi &, 465 &, 034 &, 546 & 13,784 &, 000 \\
& Pelatihan &, 116 &, 056 &, 132 & 2,086 &, 039 \\
& Pengawasan &, 329 &, 059 &, 354 & 5,609 &, 000 \\
\hline
\end{tabular}

a. Dependent Variable: Kinerja

Sumber: Data diolah, 2020

Berdasarkan Tabel 10 hasil uji parsial diperoleh dengan hasil:

Uji hipotesis parsial variabel kompetensi dari tabel tersebut dapat dilihat nilai thitung variabel kompetensi $\left(\mathrm{X}_{1}\right)$ adalah sebesar 13,784 dengan nilai signifikan 0,000 maka hasil penelitian menunjukkan hipotesis $\mathrm{H}_{1}$ diterima karena $t_{\text {hitung }}>\mathrm{t}_{\text {tabel }}(13,784>$ 1,981) dan signifikan lebih kecil dari 0,05 yang berarti bahwa variabel kompetensi berpengaruh positif dan signifikan terhadap variabel kinerja karyawan pada PT Rubber Hock Lie.

Uji hipotesis parsial variabel pelatihan dari tabel tersebut dapat dilihat nilai thitung variabel pelatihan $\left(\mathrm{X}_{2}\right)$ adalah sebesar 2,086 dengan signifikan 0,039 maka hasil penelitian menunjukkan hipotesis $H_{1}$ diterima karena $t_{\text {hitung }}>t_{\text {tabel }}(2,086>1,981)$ dan signifikan lebih kecil dari 0,05 yang berarti bahwa variabel pelatihan berpengaruh positif dan signifikan terhadap variabel kinerja karyawan pada PT Rubber Hock Lie.

Uji hipotesis parsial variabel pengawasan dari tabel tersebut dapat dilihat nilai thitung variabel pelatihan $\left(\mathrm{X}_{3}\right)$ adalah sebesar 5,609 dengan signifikan 0,000 maka hasil penelitian menunjukkan hipotesis $\mathrm{H}_{1}$ diterima karena $t_{\text {hitung }}>\mathrm{t}_{\text {tabel }}(5,609>1,981)$ dan signifikan lebih kecil dari 0,05 yang berarti bahwa variabel pengawasan berpengaruh positif dan signifikan terhadap variabel kinerja karyawan pada PT Rubber Hock Lie.

\section{KESIMPULAN DAN SARAN}

\section{Kesimpulan}

Dari hasil penelitian dan pembahasan, maka dapat ditarik kesimpulan sebagai berikut: 1).Hasil pengujian secara parsial menunjukkan bahwa kompetensi berpengaruh positif dan signifikan terhadap kinerja karyawan pada PT Rubber Hock Lie Sunggal, Sumatra Utara. 2).Hasil pengujian secara parsial menunjukkan bahwa pelatihan berpengaruh positif dan signifikan terhadap kinerja karyawan pada PT Rubber Hock Lie Sunggal, Sumatra Utara. 3).Hasil pengujian secara parsial menunjukkan bahwa pengawasan berpengaruh positif dan signifikan terhadap kinerja karyawan pada PT Rubber Hock Lie Sunggal, Sumatra Utara.

Hasil pengujian secara simultan menunjukkan bahwa kompetensi, pelatihan dan pengawasan berpengaruh positif dan signifikan terhadap kinerja karyawan pada PT 
Rubber Hock Lie Sunggal, Sumatra Utara. Nilai koefisien determinansi adjusted R2 dari pelatihan dan komunikasi menjelaskan variabel kinerja karyawan pada PT Rubber Hock Lie Sunggal, Sumatra Utara sebesar 93,7\% dan sisanya sebesar 6,3\% dijelaskan oleh variabel-variabel independen lain yang tidak diteliti.

\section{Saran}

Adapun saran yang ingin penulis sampaikan berdasarkan kesimpulan sebelumnya adalah sebagai berikut: 1).Dengan penelitian yang dilakukan ini maka peneliti berharap dapat memperoleh lebih banyak pengetahuan mengenai pengaruh kompetensi, pelatihan dan pengawasan terhadap kinerja karyawan dalam sebuah perusahaan. 2).Dengan penelitian yang dilakukan ini diharapkan dapat menambah jumlah hasil karya mahasiswa yang dapat dijadikan refrensi yang baik bagi peneliti selanjutnya. 3)>Diharapkan PT Rubber Hock Lie Sunggal, Sumatra Utara dapat meningkatkan kompetensi karyawan, memperbaiki kegiatan pelatihan kerja sehingga hasil pemberian pelatihan kerja dapat membuat karyawan lebih mengerti pekerjaannya dan mampu mengerjakan pekerjaan dengan baik serta meningkatkan kualitas pengawasan yang baik agar tujuan perusahaan dapat tercapai.

Sebagai bahan acuan dan agar dapat diamati variabel lainnya yang dapat mempengaruhi kinerja karyawan seperti motivasi, seleksi, kompensasi, pendidikan, lingkungan kerja dan sebagainya.

\section{DAFTAR PUSTAKA}

Bangun,Wilson. (2012). Manajemen Sumber Daya Manusia, Erlangga: Jakarta

Distyawaty. (2019). Pengaruh Kompetensi Dan Pengembangan Karir Terhadap Kinerja Aparatur Pengawas Inspektorat Daerah Provinsi Sulawesi Tengah.KATALOGIS, 5(4).56-68

Ghozali, Imam. (2016). Aplikasi Analisis Multivariete dengan Program IBM SPSS 21. Universitas Doponogoro: Semarang

Hamali, Arif Yusuf. (2016). Manajemen Sumber Daya Manusia. CAPS (Center for Academic Publishing Service): Yogyakarta

Hasibuan, Malayu. (2016). Manajemen Sumber Daya Manusia. PT. Bumi Aksara: Jakarta Kasmis. (2016). Manajemen Sumber Daya Manusia . Rajawali Pers: Jakarta

Mangkunegara, Anwar prabo. (2017). Manajemen Sumber Daya Manusia, PT. Remaja Rosdakarya: Bandung

Mubarok, Saefuddin. (2017). Manajemen Sumber Daya Manusia, Media: Bogor

Noor, Juliansyah. (2011). Metodologi Penelitian, Prenada media Group: Jakarta

Notoatmodjo, Soekidjo.(2015). Pengembangan SDM, Rineka Cipta: Jakarta

Rabiaful Akbar, Jumiati Sasmita, Liswar, Hamid. (2014). Pengaruh Pengawasan dan Kompetensi Terhadap Kinerja Karyawan Pada Hotel Permai Pekanbaru

Serdamaryanti. (2015). Manajemen Sumber Daya Manusia. PT. Refika: Bandung

Siagian, Sondang. (2015). Manajemen Sumber Daya Manusia. PT.Bumi Aksara: Jakarta Sugiyono.(2011). Meteologi Penelitian Pendidikan. Alfabeta: Bandung

Sunarti, Rasyid, dan Gunawan. (2017). Pengaruh Kepemimpinan, Kompetensi, dan Pelatihan Terhadap Kinerja Pegawai Bagian Umum Sekretariat Daerah Kabupaten Soppeng. Jurnal Mirai Management, 2(1), 91-107

Sunyoto, Danang. (2016). Manajemen dan Pengembangan Sumber Daya Manusia, CAPS: Yogyakarta.

Sutrisno, Edy.(2009). Manajemen Sumber Daya Manusia. Kencana: Jakarta Umam, Khaerul. (2010). Perilaku Organisasi. CV. Pustaka Setia: Bandung Umam, Khaerul.(2018). Perilaku Organisasi. CV. Pustaka Setia: Bandung Wibowo. (2014). Manajemen Kinerja. PT.Raja Grafindo Persada: Depok 